\title{
ON TWO MIOCENE GASTROPODS FROM ROUMANIA.
}

By R. Bullen Newton, F.G.S., etc.

Read 16th June, 1905.

The Gastropod shells referred to in this paper were obtained by Lieut.-Colonel Thomas English, F.G.S., from the neighbourhood of Bustenari (Province of Prahova), a place twelve miles north of Ploesci in Roumania. Both specimens are of Miocene Tertiary age, but belong to different divisions of that period. The older represents a new species of the marine genus Septa, and may be referred to the Tortonian stage; the younger is an example of the peculiar shell Valenciennesia, which is characteristic of the fresh-and brackish-water deposits forming the uppermost part of the Miocene formation, and known as the Pontian Series, the fauna of which is analogous to that existing at the present day in the saline waters of Lake Aral and the Caspian Sea.

The geology of this part of Roumania has been mainly studied by Coquand, ${ }^{1}$ Pilide, ${ }^{2}$ Andrussow, ${ }^{3}$ and Sabba Stefanescu ${ }^{4}$; the most ancient fossiliferous rocks being apparently of Eocene age, are succeeded by Oligocene and the various members of the Miocene period, with the exception of the Burdigalian beds, which are not present in this immediate area of the country.

In tabular order, from the youngest group of beds downwards, the stratigraphical sequence is as follows :-

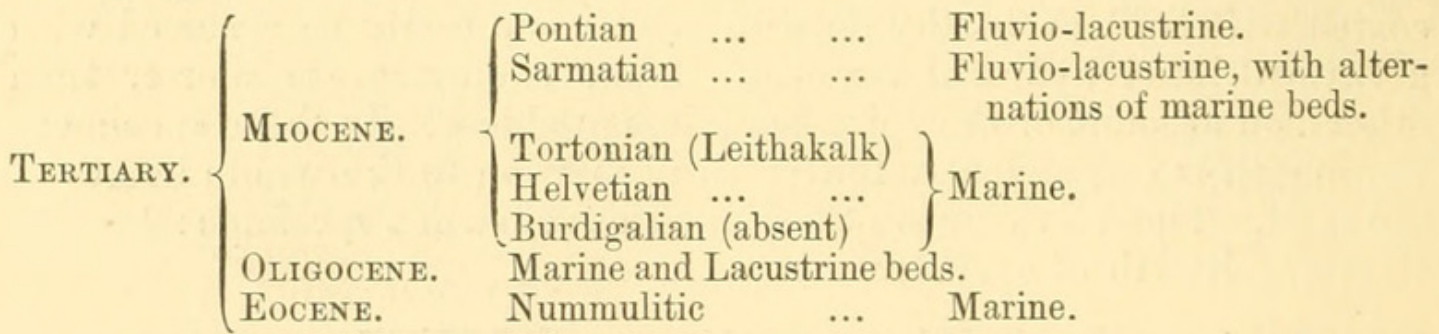

It is satisfactory to note that Colonel English has presented these specimens to the Geological Department of the British Museum.

\section{Septa Englishi, n.sp.}

Specimen massive, ventricose; whorls inflated, deep, irregular, descending obliquely from suture, subangulate posteriorly; ornamentation consisting of two distant rows of large, rounded, sometimes

1 H. Coquand, "Sur les Gîtes de pétrole de la Valachie et de la Moldavie, et sur l'âge des terrains qui les contiennent": Bull. Soc. géol. France, sér. II, vol. xxiv (1867), pp. 505-569.

2 C. D. Pilide, "Sur le Bassin Néogène de la région située an nord de Ploesci (Valachie) ": Bull. Soc. géol. France, sér. III, vol. vi (1878), pp. 22-31.

3 N. Andrussow, "Kurze Bemerkungen über einige Neogenablagerungen Rumäniens": Verhandl. k.k. Geol. Reichs., 1895, pp. 189-197.

¿ S. Stefanescu: “E'tudes sur les Terrains tertiaires de Roumanie (Thèse),” Lille, 1897 , pp. 178, with geological map. 
triangular and V-shaped tubercles, which, on the body-whorl, form a kind of double angulation; aperture pyriform; inner lip with a thin, spreading callus; outer lip varixed. Height of specimen 120, of last whorl $97 \mathrm{~mm}$.; greatest diameter of last whorl 87, smallest $75 \mathrm{~mm}$.

Locality.-Near Bustenari, Roumania.

Formation.-Miocene (Tortonian).

This fragmentary specimen, showing the usual irregularities in the spire of this genus, consists mainly of a natural cast, very little of the original shell remaining. It shows the two last whorls and portion of a third, and, although so imperfect, the specimen represents one of the largest forms of this genus found in Tertiary rocks. The dorsal view (Fig. II) exhibits an expansive, swollen body-whorl, with a wide,

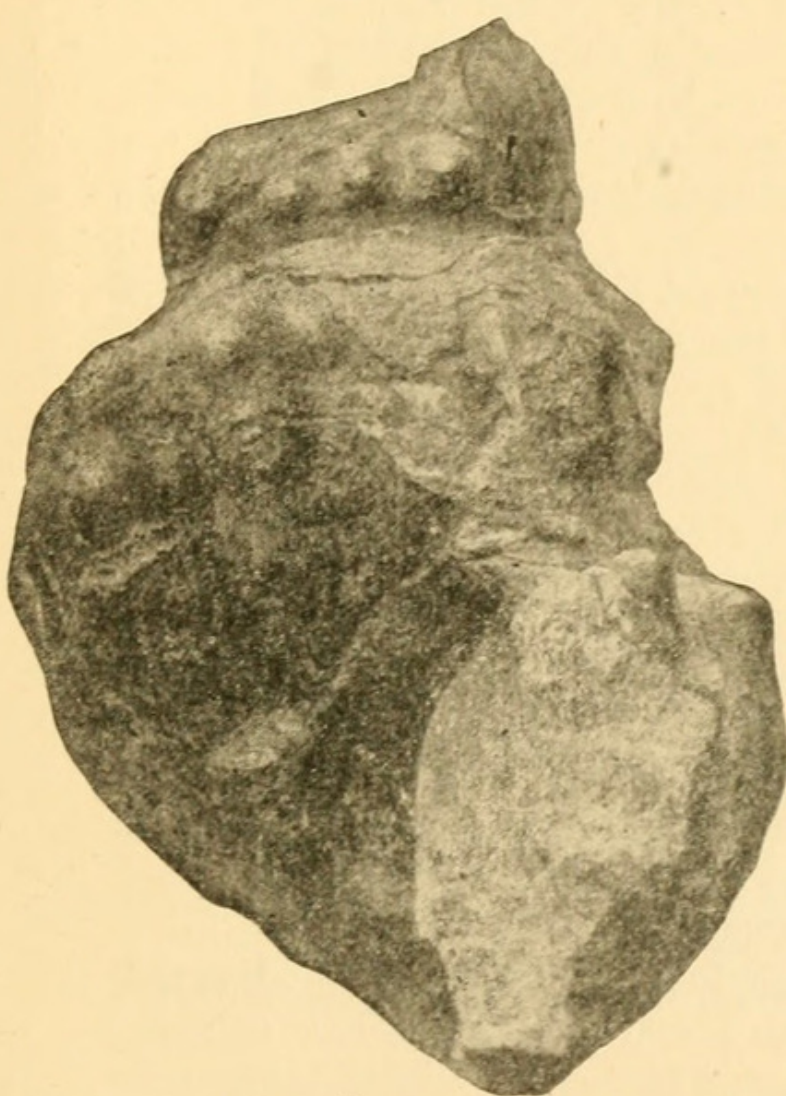

I.

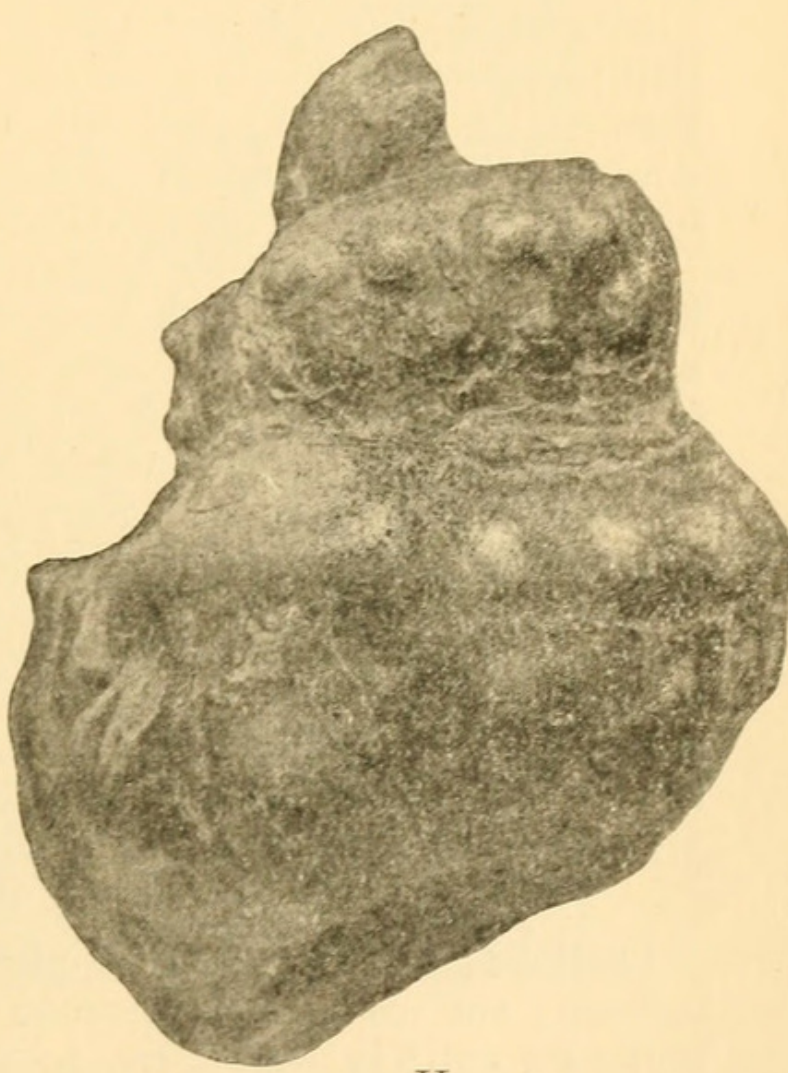

II.

oblique surface extending from the suture to a sub-angulate margin formed by a series of large, rounded tubercles, beneath which, and parallel to them, is a similar row of tubercles; in the region of the outer lip these tubercles are much elevated, besides being triangular or V-shaped, with their apices directed towards the mouth.

The ventral aspect (Fig. I) shows the columella to be much excavated, whilst the inner lip is covered with the remnants of a thin callus; the labrum is distinctly varixed, but its internal characters are hidden with matrix; near the posterior corner of the aperture are two prominent triangular tubercles; the anterior canal is not present.

This fossil is most nearly related to $S$. nodifera (Lamarck), found in the Middle Miocene rocks of the Vienna Basin, Italy, etc., although much more massive in its proportions, whilst the whorls are deeper 
and more swollen; the tuberclęs are, however, very similar in both forms, but smaller and rounder in $S$. nodifera. Stefaneseu has recorded the occurrence of Septa Apenninica (Sassi) and S. Grasi (Bellardi) in the Tortonian beds of South-Western Roumania (Bahna, Verciorova, etc.), but these species are in no way related to the present shell, being of much smaller size and bearing an entirely different ornamentation. There is no doubt that the horizon of this shell may be given as Tortonian, since a microscopical examination of the matrix discloses the presence of a nullipore structure of the genus Lithothamnium, a marine alga which largely constitutes the socalled 'Leithakalk' of the Vienna Basin, and which is characteristic of the Tortonian division of the Miocene system. Such Miocene rocks have already been recorded from near slanic, in the neighbourhood of Bustenari, by Dr. Pilide, ${ }^{1}$ who recognized the occurrence of similar nullipores in the limestone, accompanied by a number of marine shells, thus enabling him to correlate the deposits with the 'Leithakalk' of Austria. The specimen is of a brownish-black colour, having been found in association with petroleum.

The generic name of Septa here adopted for this shell was founded by Perry in 1811 ("Conchology, or the Natural History of Shells," pl. xiv, explanation) for a number of species belonging to Cymatium of Bolten and Triton of De Montfort. As De Montfort's Triton was previously occupied by Linnæus for another animal, Dr. W. H. Dall has selected Septa to take its place, recognizing Septa rubicunda of Perry as the type, which is said to be equivalent to Triton nodiferum of Lamarck. Septa will also include the second part of Schumacher's Lampusia, of which the type is Murex tritonis, Linnæus. For fuller information on this subject the student should consult Dr. Dall's pamphlet entitled "An Historical and Systematic Review of the FrogNhells and Tritons," published August 6th, 1904, in the Smithsonian Miscellaneous Collections, vol. xlvii, Pub. No. 1467, p. 114.

\section{Valenciennesia Roumaniensis, n.sp.}

Shell orbicular, pileiform, fragile ; apical region posterior, elevated, inflated ; surface depressed beyond the apical area to anterior margin; sculpture entirely concentric, possessing numerous equidistant, deep sulcations margined by rounded or bluntly-edged, elevated, regular ridges (about 24), except towards anterior region, where the sulcations are shallower, and the ridges become merged together and less definite.

Height 58, width 46, convexity of apical region $12 \mathrm{~mm}$.

Locality - Near Bustenari, Roumania.

Formation.-Miocene (Pontian).

This species is intermediate between $V$. Pauli of Hoernes ${ }^{2}$ and $V$. annulata of Reuss. ${ }^{3}$ From the former it differs in its much smaller

1 C. D. Pilide, “Ueber das Neogen-Becken nördlich von Ploesci (Walachei):" Jahrb. k.k. Geol. Reichs., vol. xxvii (1877), pp. 134, 135.

2 Rudolf Hoernes, “Ein Beitrag zur Kentniss der Neogen-Fauna von Süd-Steiermark und Croatien-Congerien- (Valenciennesien-) Schichten von Kneginec": Jahrb. k.k. Geol. Reichs., vol. xxv (187j), p. 72, pl. iii, fig. 1.

3 A. E. Reuss, "Neue Fundorte von Valenciennesia annulata", Sitz. k. Akad. Wiss. Wien, vol. lvii (1868), pp. 92-102, pl. iii, figs. 1-3. 
size and the possession of closer concentric sculpture, from the latter in having a more rounded contour and in showing closer and more numerous concentric ridges and grooves.

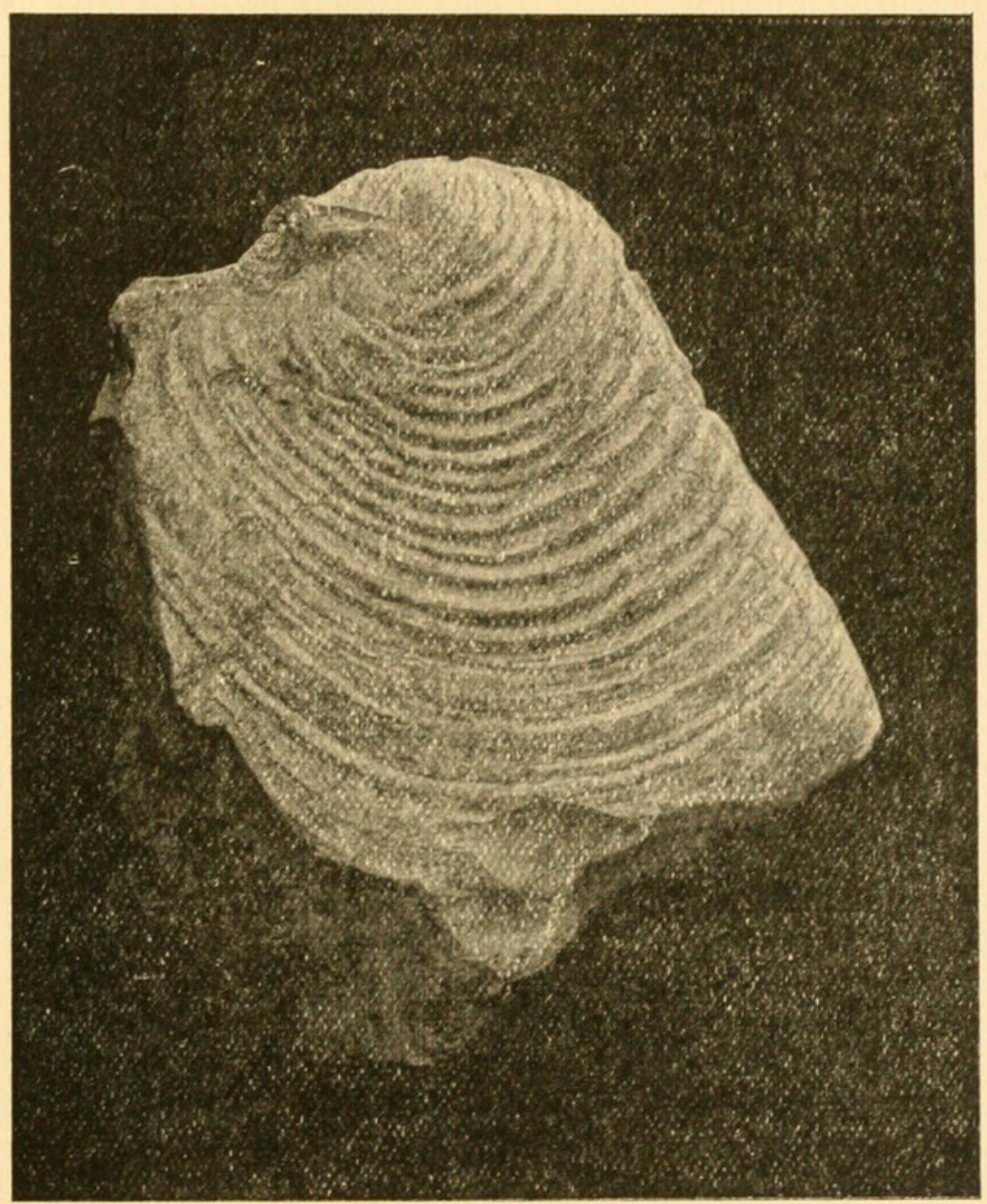

The specimen described is much flattened, forming a kind of impression on the stiff greyish clay to which it is attached. It is, moreover, incomplete on the left side, the original margin having been worn away, but the concentric sculpture and definite border-line of the remaining part of the shell offer sufficient evidence for a complete restoration, if required, of its entire external contour. The condition of preservation is much the same as controls most examples of this genus, with the exception, perhaps, of Rousseau's ${ }^{1}$ original type of $V$. annulota, which has a beautifully oval, arched, convex test, widely sculptured, sulcated surface, and non-spiral summit, displaying on the right side of the apex the characteristic swollen plication extending

1 L. Rousseau, "Description des principaux Fossiles de la Crimée": A. de Demidoff's “ Voyage dans la Russie Méridionale et la Crimée,"' 1842, vol. ii, p. 791, atlas, pl. iii, fig. 7 . 
from that point to the posterior margin. Such a plication exists in the specimen from Roumania, and, though somewhat obscure, it appears to have been a kind of narrow tube-like process leading from the apical region to the [absent] posterior border, and which internally would have corresponded with a longitudinal groove. The apex of this specimen is also wanting, its immediate area being obtuse or rounded.

The few species comprised in this genus certainly require some revision, if only suitable material were available for examination, from the fact that Reuss appears to have misinterpreted Rousseau's original type of $V$. annulata, which showed an external sculpturing of an Inoceramoid type, as well as a cancellated structure. The $V$. annulata of Reuss referred to a shell much more orbicular in contour, having a greater number of concentric ridges and grooves, and therefore closer together, and without evidence of surface cancellation. Judging from the figures, it would appear that Reuss' shell is not a great way removed from $V$. Pauli of Kudolf Hoernes, found in the Pontian beds of Croatia, and possibly the present form might be united to both, but, in the absence of better specimens for study, it is provisionally regarded as a new species under the name of $\vec{V}$. Roumaniensis. Rousseau originally pointed out that this Pulmonate genus showed resemblances to Ancylus and Siphonaria, whilst Fischer in his "Manuel" (p. 502) has doubtfully placed it in the family Otinidæ and close to Benson's Camptonyx. In the case of Camptonyx, which is an Indian terrestrial shell, there are some features in common with Valenciennesia, viz., its pileiform shape, regular rugose surface, and the presence of an external swollen rib to the right of the summit; it differs, however, in possessing a sub-spiral instead of non-spiral apex, besides being of extremely small size, measuring only about $10 \mathrm{~mm}$. in height. Ancylus, again, although of fresh-water habit, is of patelliform shape, with a spiral summit, and covered with fine and delicate radial markings; whilst Siphonaria is a marine genus, differing by being patelliform and showing sculpture with radiating costæ, but bearing a prominent external rib on the right margin.

In further comparison the following remarks by Benson, made at the conclusion of his paper on Camptonyx, are of interest:-

"The littoral genus Siphonaria, which Dr. Gray places between the Auriculidæ and Cyclostomidæ, is remarkable for the presence of a deep siphonal groove on the right side. Again, the large Tertiary fossil genus Valenciennia, Rousseau, supposed to have been an inhabitant of brackish water, has a channel running from the under side of the beak of the shell to the right side of the aperture, much like the dorsal one of Camptonyx. It is supposed by M. Bourguignat to serve as a sheath to a siphonal tube. It probably communicates, as in Camptonyx, with the respiratory orifice, and does not necessarily contain a special organ. The strong concentric ribs of Valenciennia present a curious analogy to the rugose surface of Camptonyx."

Valenciennesia is a characteristic genus of the fresh- and brackishwater Pontian deposits (= Congerien Schichten) which belong to the uppermost part of the Miocene system, and which extend from the 
Vienna Basin through Hungary, Croatia, Dalmatia, Roumania to Southern Russia. Rousseau originally described it from the neighbourhood of Kertch in the Crimea, where it was found associated with Limnea velutina, Deshayes, Limnaa peregrina, Deshayes, Paludina casaretto, Rousseau, and Planorbis rotella, Rousseau (see Bourguignat); Congeria aperta, Deshayes, Cardium planum, ${ }^{1}$ Desh., C. carinatum, Desh., C. crenulatum, Rousseau, C. acardo, Desh., and C. modiolare, Rousseau (see Reuss).

Since then it has been recorded by Reuss from near Arcani in SouthWestern Roumania, and from near Gran in Hungary (Sitz. k. Akad. Wiss. Wien, 1868, vol. lvii, pl. iii, figs. 1-3, pp. 92-101). Oscar Lenz refers to its occurrence at Beocsin, Slavonia (Jahrb. k.k. Geol. Reichs., 1873, vol. xxiii, pp. 295-316); Brusina has obtained it from Agram in Croatia (Fossile Binnen-Mollusken, etc., 1874, pp. 102, 103); Dr. Sabba Stefanescu records it from the district of Gorjiu, SouthWestern Roumania, an area contiguous to that whence Reuss obtained his examples described in 1868 (Études sur les Terrains tertiaires de Roumanie: Mém. Soc. Géol. France, 1896, Mém. No. 15, pl. ix, figs. 34,35 , pp. 103-105); and Hoernes has also described it from Croatia (Jahrb. k.k. Geol. Reichs., 1875, vol. xxv, p. 72, pl. iii, fig. 1).

It may be mentioned that the generic name has undergone various orthographical changes. Rousseau dedicated the shell to Professor Valenciennes of Paris, but unfortunately adopted two renderings of it in his monograph, viz., in the text as Valenciennius and on the plate as Valenciennensis. To correct this want of uniformity Bourguignat $^{2}$ suggested Valenciennia, and lastly Paul Fischer ${ }^{3}$ more accurately defined the Latinized version of the name by introducing Valenciennesia, which is now generally accepted.

1 As the different species of Cardium here enumerated are of brackish-water or lacustrine origin, and moreover differ internally (teeth, etc.) from the true marine forms of the genus, they are now recognized under other generic names, as follows: Phyllocardium planum, P. depressum (= crenulatum); Pontalmyra carinata, P. modiolaris; Arcicardium acardo.

2 J. R. Bourguignat, "Aménités Malacologiques"': Revue et Magasin Zoologie (Paris), ser. II, vol. vii (1855), p. 29, pls. i and ii.

3 P. Fischer, "Des genres Camptonyx et Valenciennesia"': Journ. Conchyl., vol. vii (1858), p. 318. 


\section{$2 \mathrm{BHL}$ Biodiversity Heritage Library}

Newton, R Bullen. 1905. "ON TWO MIOCENE GASTROPODS FROM

ROUMANIA." Proceedings of the Malacological Society of London 6, 340-345.

View This Item Online: https://www.biodiversitylibrary.org/item/52315

Permalink: https://www.biodiversitylibrary.org/partpdf/202895

\section{Holding Institution}

Smithsonian Libraries

\section{Sponsored by}

Smithsonian

\section{Copyright \& Reuse}

Copyright Status: Public domain. The BHL considers that this work is no longer under copyright protection.

This document was created from content at the Biodiversity Heritage Library, the world's largest open access digital library for biodiversity literature and archives. Visit BHL at https://www.biodiversitylibrary.org. 